\title{
Abnormal histology in testis from prepubertal boys with monorchidism
}

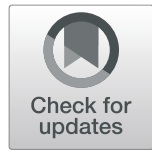

Faruk Hadziselimovic ${ }^{*}$, Gilvydas Verkauskas ${ }^{2}$, Beata Vincel ${ }^{2}$, Gunthild Krey ${ }^{1}$ and Zacharias Zachariou ${ }^{3}$

\begin{abstract}
Background: Little is known about the histology of contralateral descended testes in boys with unilaterally absent testis. We investigated whether absence of one testis is associated with abnormal tissue architecture of the solitary contralaterally descended testis.

Design, setting, and patients: For this retrospective study, we examined the results of biopsies of the contralateral descended testis in 43 boys with monorchidism. Data from 26 control testes from boys of matching ages were selected from results published in 1977 and 2009. During surgery, any nubbins were removed. In each case, the scrotal testis was biopsied, and the testis fixed by subdartos pouch or suture.

Results: Of the 43 affected boys, 23 had normal testicular histology in the contralateral descended testis, whereas 20 (46\%) had abnormal histology. Eight of the abnormal biopsies matched the criteria for high infertility risk. Samples from three boys in this latter group revealed a Sertoli-cell-only phenotype. Immunohistochemical assays were positive for steroidogenic acute regulatory (STAR) protein in Leydig cells and spermatogonia. STAR expression was stronger in the monorchid group with normal testicular histology.

Conclusions: Almost half of the patients with unilateral absent testis were at risk for subfertility or infertility. Our results emphasize the need for testicular biopsy of the solitary testis in boys with monorchidism to appropriately assess infertility risk.
\end{abstract}

Keywords: Monorchid testis, Histology, Immunohistochemistry, Fertility STAR

\section{Résumé}

Contexte: Peux d'études ont analysé la structure des tissus testiculaires des testicules descendus controlatéraux chez les garçons avec des testicules unilatéraux absents. Nous avons investigué si l'absence congénitale d'un testicule est. associée à une histologie anormale des testicules descendus controlatéraux solitaires.

(Continued on next page)

\footnotetext{
* Correspondence: praxis@kindermedizin-zentrum.ch

'Institute for Cryptorchidism Research Liestal, Children's Day Care Center Liestal, 4410 Liestal, Switzerland

Full list of author information is available at the end of the article
}

C C The Author(s). 2020 Open Access This article is licensed under a Creative Commons Attribution 4.0 International License, which permits use, sharing, adaptation, distribution and reproduction in any medium or format, as long as you give appropriate credit to the original author(s) and the source, provide a link to the Creative Commons licence, and indicate if changes were made. The images or other third party material in this article are included in the article's Creative Commons licence, unless indicated otherwise in a credit line to the material. If material is not included in the article's Creative Commons licence and your intended use is not permitted by statutory regulation or exceeds the permitted use, you will need to obtain permission directly from the copyright holder. To view a copy of this licence, visit http://creativecommons.org/licenses/by/4.0/ The Creative Commons Public Domain Dedication waiver (http://creativecommons.org/publicdomain/zero/1.0/) applies to the data made available in this article, unless otherwise stated in a credit line to the data. 
(Continued from previous page)

Conception, contexte et patients: Cette étude rétrospective a examiné les résultats des biopsies des testicules descendus controlatéraux de 43 garçons monorchides. Les données de 26 testicules témoins ont été appariées surl'âge et sélectionnées à partir des données publiées en 1977 et 2009. Pendant l'opération, les nubins (reliquats) détectés ont été enlevés. Dans chaque cas, les testicules scrotaux ont fait l'objet d'une biopsie et d'une fixation par la technique de la valise ou par suture au subdartos.

Résultats: Parmi 43 garçons, 23 avaient une histologie testiculaire normale dans les testicules descendus controlatéraux, tandis que 20 (46\%) avaient une histologie anormale. Huit biopsies anormales correspondaient aux critères de risque élevé d'infertilité. Trois garçons de ce groupe avaient une histologie testiculaire montrant la présence de cellules Sertoli seules. L'analyse immunohistochimique de la protéine STAR a montré un signale dans les cellules de Leydig et dans les spermatogonies. L'expression STAR était plus forte dans le groupe des monorchides avec une histologie testiculaire normale.

Conclusions: Près de la moitié des patients ayant des testicules congénitaux unilatéraux absents couraient un risque d'hypofertilité ou d'infertilité. Nos résultats soulignent la nécessité d'une biopsie testiculaire des testicules solitaires chez les garçons monorchides afin d'évaluer le risque d'infertilité de ces patients.

Mots-Clés: Testicule unique, Histologie, Immunohistochimie, Fertilité, Protein STAR

\section{Introduction}

A unilaterally absent testis (monorchidism) is thought to be caused by prenatal or antenatal testicular torsion. The absent testis may be explained either by a twisted undescended gonad or twisted normal gonad that vanished because of events following complete descent. Therefore, vanishing testes and their descended counterparts may not be subject to the endocrinopathy that affects cryptorchid testes because torsion, the probable cause of monorchidism, is thought to occur along the path into the scrotum [1]. Of note, boys with cryptorchidism have a 10fold higher incidence of testicular torsion compared to boys without cryptorchidism [2]. Histological examination of descended single testes in boys with a unilateral nubbin has revealed increased germ cell proliferation and dissimilar maturation patterns compared to the contralateral descended gonad in boys with unilateral cryptorchidism [3]. These findings point to antenatal torsion resulting from a mechanical event rather than endocrinopathy as the etiology for absent testis $[3,4]$. The presence of a contralateral descended testis after nubbin excision raises concerns about future fertility. Normal histology of the monorchid testis [3] and normal paternity [5], as well as oligozoospermia [6] and azoospermia [7], have been observed in these patients. Here, we present histopathological results showing that half of the boys with monorchidism included in our study had pathologic testicular histology. This result is consistent with and may explain the increased incidence of subfertility or even infertility in males with unilateral absent testis.

\section{Patients and methods}

Following approval by our institutional ethical committee, we conducted a retrospective database review that identified 43 boys who had undergone surgery for non- palpable testis. Inclusion criteria consisted of a preoperative diagnosis of a nonpalpable undescended testis and either the presence of a testicular nubbin or absent testis with blind-ending gonadal vessels and vas deferens at surgical exploration. During surgery, all testicular remnants (nubbins) detected were removed. Vanishing testes were confirmed during inguinal surgeries. In addition, the scrotal descended testis was biopsied in each case and fixed by subdartos pouch or suture.

Boys with monorchidism with or without a nubbin that completely lacked testicular tissue were included in the study. Investigated patients neither had chromosomal anomalies nor "re-do" surgeries performed earlier in life. Four boys with normal and 3 boys with abnormal testicular histology were hormonally treated prior to the surgery. All tissue samples were immediately fixed in $2 \%$ glutaraldehyde in phosphate buffer, embedded in epoxy resin, sectioned at a thickness of $1 \mu \mathrm{m}$, and stained with toluidine blue. Histological analysis was performed using light microscopy at $60 \times$ total magnification. For each biopsy, at least 100 seminiferous tubules were examined. Histological data included the total number of germ cells, the number of A dark (Ad) spermatogonia, and the presence of primary spermatocytes. Exclusion criteria were age $>18$ years and missing data for any of the histological variables. Germ cell counts from the contralateral descended testis group and from a historical control group were compared. For the latter, data from 26 control testes, most of them obtained post-mortem, were selected from data published and age-matched $[8,9]$.

\section{Immunohistochemistry}

16 testicular biopsies were analyzed (8 in each group). Fresh performed slides were blindly evaluated by two examiners experienced in immunohistology. 
Immunohistochemistry was performed for steroidogenic acute regulatory (STAR) protein which is important in steroid hormone synthesis. It enhances the metabolism of cholesterol into pregnenolone by mediating the transfer of cholesterol to the inner mitochondrial membrane [10]. RNA-binding protein Sam68 belongs to the evolutionary conserved signal transduction and activation of RNA (STAR) family. It is required for the correct progression of spermatogenesis and for male fertility in the mouse and probably human [11]. Moreover, the decreased expression of Sam68 has been shown in human testes with spermatogenic defects demonstrating its role in the regulation of germ cells [12].

For immunohistochemical analysis, epon was removed from the tissue sections. The sections were treated with $2 \%$ bovine serum albumin to reduce non-specific binding and then incubated with the primary antibody overnight at $4{ }^{\circ} \mathrm{C}$. All samples were washed with phosphatebuffered saline between incubations. We used an antibody targeting the steroidogenic acute regulatory (STAR) protein (Santa Cruz sc-166,821), labeled with horseradish peroxidase-polymer (HRP; goat polyclonal anti-rabbit IgG, mouse IgG and IgM, prediluted ab2891, Abcam, Cambridge, UK) to detect the binding of the primary antibody. The chromogenic reaction was developed by adding a freshly prepared solution of 3,3diaminobenzidine solution (DAB + chromogen; DAKO). The DAB reaction was terminated by washing in Trisbuffered saline $(0.05 \mathrm{M}$ Tris-buffered saline and $0.85 \mathrm{M}$ $\mathrm{NaCl}, \mathrm{pH}$ 7.6). To allow visualization of testicular cells, the samples were counterstained with toluidine blue. Antibody binding was indicated by a brown precipitate. Different cell types were identified based on their nuclear morphology and position within the gonad. Immunohistochemistry experiments were performed at least three times on samples from at least eight patients from each group, and only those with identical results between experiments for each sample were included in the study. Controls for non-specific binding of the secondary antibody were performed in all experiments by omitting the primary antibody; these experiments consistently yielded no signal within the seminiferous epithelium or the interstitial space. Experimental design, biomaterials and treatments, reporters, staining, imaging data, and image characterization were performed in compliance with the minimum information specification for immunohistochemistry experiments [13].

\section{Statistical analysis}

The software package StatXact 6.30 (2004, CYTEL Corporation) was used to apply the Mann-Whitney U test of unpaired data. In addition, Fisher's exact test was applied, and $p<0.01$ was considered to indicate significance.

\section{Results}

Biopsy data were available for 43 prepubertal patients with absent unilateral testes. The mean total spermatogonia count was $2.3 \pm 1.5$ (95\% confidence interval [CI] 1.8-2.8), and the mean Ad spermatogonia count for the whole group was $0.127 \pm 0.129$ (95\% CI 0.008-0.16) per tubular cross section. Boys with monorchidism whose testis showed normal histology had a mean age of $2.79 \pm$ 3.8 (95\% CI 0.96-4.62) years at the time of surgery, which did not differ significantly from that of boys with monorchidism and abnormal testicular pathology (2.8 \pm 1.85 [95\% CI 1.58-4.08] years).

Samples from $54 \%(n=23)$ of the patients in our cohort showed normal testicular histology. The total mean count for germ cells was $2.9 \pm 1.41$ (95\% CI 2.3-3.5) per tubule, whereas for Ad spermatogonia it was $0.21 \pm 0.12$ (95\% CI 0.15-0.26) per tubule (Fig. 1). This count did not differ from that of the historical control group (Fig. 1).

In prepubertal testes, primary spermatocytes usually appear at 3-4 years of age [8]. In this study, in four of nine testes of boys with monorchidism, we observed spermatocytes at age 3-8 years (mean $0.24 \pm 0.44$ per tubular cross-section). This finding corresponds to a normal distribution in prepubertal boys with bilateral descended testes $[8,14]$. Furthermore, none of the testes from the affected group displayed spermatogenesis that had progressed beyond primary spermatocytes, which would have indicated precocious puberty.

We did identify different degrees of testicular pathology in $46 \%(n=20)$ of the affected boys. Mean values for both total germ cell count $(1.18 \pm 1.04$ [95\% CI $0.6-$ 1.6] germ cells/tubule) and Ad spermatogonia ( $0.003 \pm$ 0.002 [95\% CI 0.0018-0.0035] per tubular cross-section) were reduced (Fig. 1). Samples from eight of the affected boys showed a testicular pathology consistent with a high risk of infertility. Three of these boys had Sertoli cells only, four had no Ad spermatogonia along with a reduced total germ cell count $(>0.2<0.6$ germ cell/tubule), and one had no Ad spermatogonia and a total germ cell count of $<0.2$ germ cell/tubule. Finally, 12 boys had intermediate or low risk of infertility.

STAR immunoreactivity was observed exclusively in the cytoplasm in a granular pattern regardless of the tissue type studied. STAR was found in germ cells and Leydig cells. It was strongly expressed in testes with normal histology $[4+]$ but only weakly so $[1+]$ in testes with abnormal histology (Figs. 2 and 3).

\section{Discussion}

In one study covering cases from 1985 to 1991, absent testes were diagnosed in $10 \%$ of 1225 patients examined for cryptorchidism [15]. Pathological studies of the remnants revealed a vas deferens in 89 cases (81\%), epididymal tissue in 40 (36\%), and small amounts of 


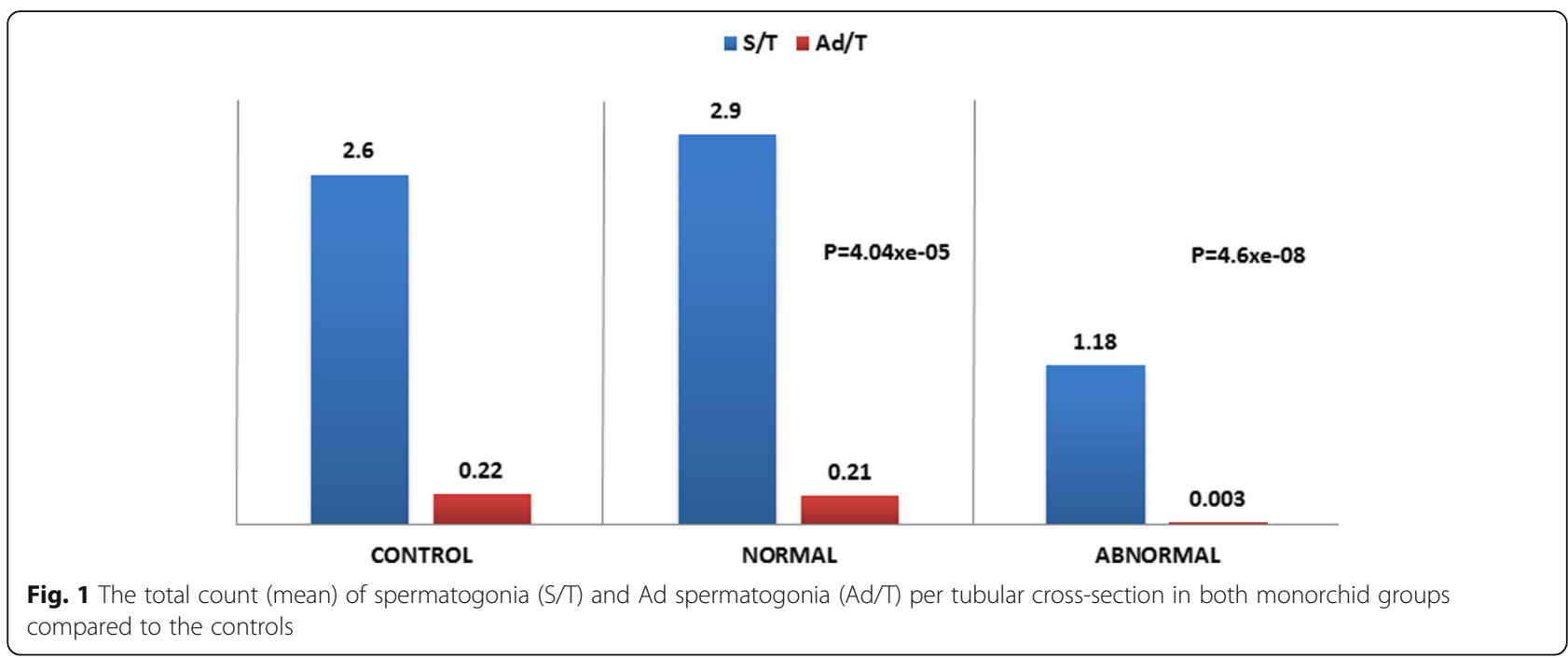

seminiferous tubules with germinal elements in seven (6.4\%) [15]. A significant number of patients showed evidence of calcification (35.5\%) and hemosiderin deposits (30\%) within the remnant, lending weight to an etiology related to torsion rather than endocrinopathy [15]. Infants with monorchidism and contralateral testicular hypertrophy showed low inhibin B levels and high follicle-stimulating hormone levels, confirming the hypothesis that a single testis cannot prevent testicular insufficiency in adulthood [16]. In another study, STAR protein was detected in adult Leydig cells but not in adult spermatogonia [17]. In this context, we note that strong expression of STAR in prepubertal testicular germ cells has not been observed before (see Fig. 2). The presence of STAR in cells that do not express cytochrome P450 suggests that in addition to stimulating pregnenolone synthesis, STAR has roles in metabolic processes. However, the exact role of STAR in prepubertal germ cells is unknown. It may function in germ cell surveillance; testes with pronounced pathology and a decreased germ cell population also exhibited decreased STAR expression (Fig. 3).

The monorchid testis in boys with a unilateral testicular nubbin is generally believed to be normal and leave prospective fertility intact $[3,5]$. Of note, Lee et al. did not find diminished paternity among men with a single testis compared to the general population, regardless of what led to the absent testis [5]. However, azoospermia

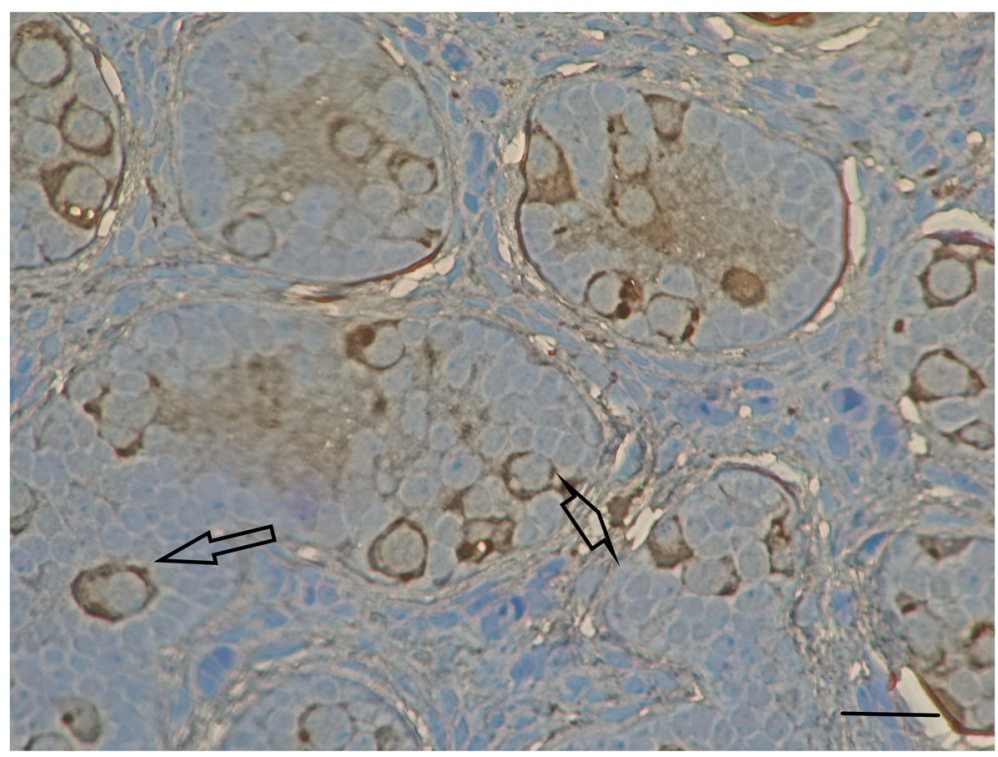

Fig. 2 STAR protein staining in a sample from a 42-month-old boy with monorchidism and normal testicular histology. Intratubular spermatogonia (arrow) display strong STAR stain (4+) as well as the Leydig cells in interstitial tissue (arrowhead). Horizontal bar $=30 \mu$ 


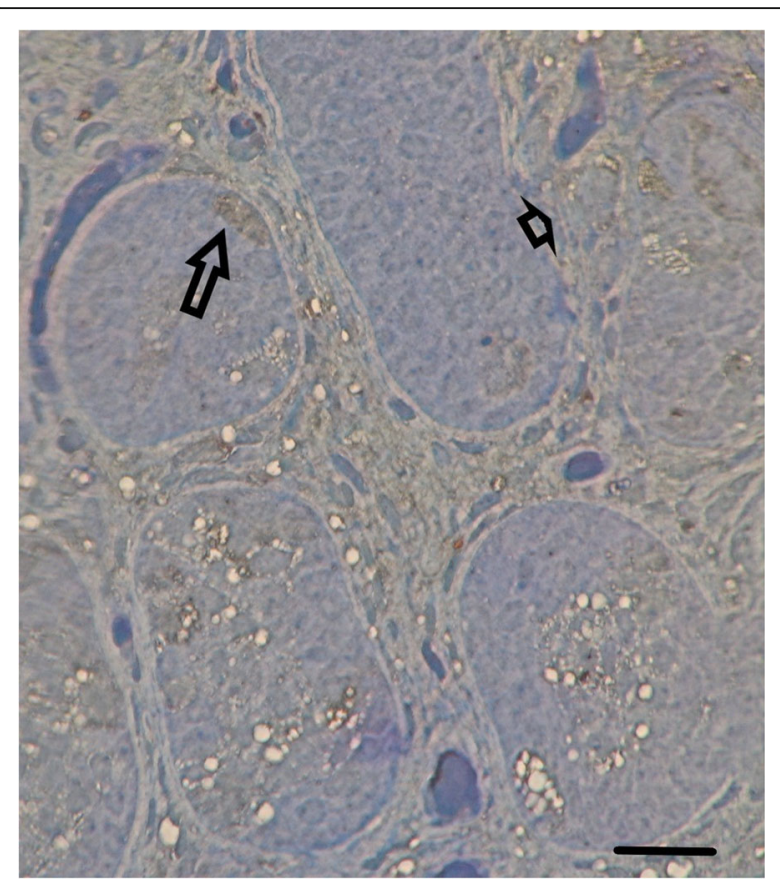

Fig. 3 Weak staining for STAR protein (1+) from a 36-months-old boy at high risk for infertility: Leydig cells (arrowhead) located between the tubules and spermatogonia located at the basal membrane (arrow) are marked. Horizontal Bar $=30 \mu$

has been reported in patients with monorchidism [7], and in one study, oligozoospermia was identified in 36\% of 47 young males who had a single descended testis [6]. In that same study, the percentage of men with oligozoospermia did not differ between the 13 who had an absent testis (38.5\%) and the $34(35.3 \%)$ with an undescended testis [6].

IFew reports have described the quality of the testicular tissue of the contralateral descended testis from boys with a unilateral testicular nubbin [3, 4]. Kraft et al. described advanced testicular maturation in a group of boys with monorchidism [3]. In the current work, we found that none of the affected boys had testicular development that had advanced beyond spermatocytes, an indicator of advanced testicular maturation. In contrast to Kraft et al.'s results of normal or advanced testicular development among all monorchid testes, we found that half of the affected population in our study showed abnormal testicular histology. Of note, 9\% of boys with monorchidism met the criteria for high risk of infertility, with a complete lack of Ad spermatogonia and a reduced total germ cell count $[18,19]$. Theoretically, abnormal testicular histology could result from some adverse effects of the contralateral nubbin. A more likely hypothesis is that boys who are predisposed to develop infertility are more prone to testicular torsion. Boys with cryptorchidism, for example, are reported to have a higher incidence of testicular torsion along the path of descent compared to unaffected boys [2].

\section{Conclusions}

In this study, we found that $46 \%$ of the patients with a congenitally absent testis on one side have an elevated risk of infertility. Therefore, boys with an absent testis should be examined by a contralateral testicular biopsy at the time of elective fixation of the solitary testis. The result will justify the application of a therapeutic regime to reduce the risk for impaired fertility in these boys. In cases in which a biopsy is not performed, the family should be advised that a sperm quality assessment should be sought for the patient in adulthood.

\section{Abbreviations \\ Ad: A dark spermatogonia; Ad/T: Number of Ad spermatogonia per tubular cross-section; STAR: Steroidogenic Acute Regulatory Protein; S/T: Number of spermatogonia per tubular cross-section}

\section{Acknowledgments}

None.

\section{Authors' contributions}

FH conceived and designed the study, interpreted the data, and wrote the manuscript. GV designed research, contributed to the paper, BV designed research contributed to the paper, GK contributed immunohistochemical data, and ZZ conceived and designed the research, analyzed data, and contributed to the paper. The author(s) read and approved the final manuscript.

\section{Funding}

None.

\section{Availability of data and materials}

Not applicable.

\section{Ethics approval and consent to participate}

In accordance with the Declaration of Helsinki, the Institutional Review Board and the Independent Ethics Committee of the Children's Clinic Liestal approved all aspects of this study. Approval was provided for research involving the use of material (data records or biopsy specimens) that had been collected for non-research purposes.

\section{Consent for publication}

Non applicable.

\section{Competing interests}

The authors declare that they have no competing interests.

\section{Author details}

'Institute for Cryptorchidism Research Liestal, Children's Day Care Center Liestal, 4410 Liestal, Switzerland. ${ }^{2}$ Children's Surgery Centre, Faculty of Medicine, Vilnius University, Vilnius, Lithuania. ${ }^{3}$ Medical School, University of Cyprus, Nicosia, Cyprus.

Received: 21 May 2020 Accepted: 12 July 2020

Published online: 06 August 2020

\section{References}

1. Belman $A B$, Rushton HG. Is the vanished testis always a scrotal event? BJU Int. 2001;87:480-3.

2. Williamson R. Torsion of the testis and allied conditions. Br J Surg. 1976;63: 465-76.

3. Kraft KH, Bhargava N, Schast AW, Canning DA, Kolon TF. Histological examination of solitary contralateral descended testis in congenital absence of testis. J Urol. 2012;187(2):676-81. 
4. Huff DS, Wu HY, Snyder HM 3rd, Hadziselimović F, Blythe B, Duckett JW. Evidence in favor of the mechanical (intrauterine torsion) theory over the endocrinopathy (cryptorchidism) theory in the pathogenesis of testicular agenesis. J Urol. 1991;146:630-1.

5. Lee PA, O'Leary LA, Songer NJ, Coughlin MT, Bellinger MF, LaPorte RE. Paternity after unilateral cryptorchidism: a controlled study. Pediatrics. 1996; 98:676-9.

6. Woodhead DM, Pohl DR, Johnson DE. Fertility of patients with solitary testes. J Urol. 1973;109:66-7.

7. Jaeger H, Delacretaz D. Monorchidism and total azoospermia. Dermatologica. 1952;105(4-5):272.

8. Hadziselimovic F. Cryptorchidism. Ultrastructure of normal and cryptorchid testis development. In: Brodal, et al., editors. Advances in Anatomy, Embryology and Cell Biology. Berlin Heidelberg, New York: Springer Verlag; 1977. p. 9-10.

9. Zivkovic D, Hadziselimovic F. Development of Sertoli cells during minipuberty in normal and cryptorchid testes. Urol Int. 2009;82(1):89-91. https:// doi.org/10.1159/000176032

10. Lin D, Sugawara T, Strauss JF 3rd, Clark BJ, Stocco DM, Speanger P, et al. Role of steroidogenic acute regulatory protein in adrenal and gonadal steroidogenesis. Science. 1995;267(5205):1828-31. https://doi.org/10.1126/ science.7892608

11. Paronetto MP, Messina V, Bianchi E, Barchi M, Vogel G, Moretti C, et al. Sam68 regulates translation of target mRNAs in male germ cells, necessary for mouse spermatogenesis. J Cell Biol. 2009;185(2):235-49. https://doi.org/ 10.1083/jcb.200811138 PMID: 19380878; PMCID: PMC2700383.

12. Li LJ, Zhang FB, Liu SY, Tian YH, Le F, Lou HY, et al. Decreased expression of SAM68 in human testes with spermatogenic defects. Fertil Steril. 2014; 102(1):61-67.e3. https://doi.org/10.1016/j.fertnstert.2014.03.036.

13. Deutsch EW, Ball CA, Berman JJ, Bova GS, Brazma A, Bumgarner RF, et al. Minimum information specification for in situ hybridization and immunohistochemistry experiments (MISFISHIE). Nat Biotechnol. 2008;26(3): 305-12. https://doi.org/10.1038/nbt1391.

14. Paniagua R, Nistal M. Morphological and histometric study of human spermatogonia from birth to the onset of puberty. J Anat. 1984;139:535-52.

15. Turek PJ, Ewalt DH, Snyder HM 3rd, Stampfers D, Blyth B, Huff DS, Duckett J. The absent cryptorchid testis: surgical findings and their implications for diagnosis and etiology. J Urol. 1994;151:718-20.

16. Gaudino R, Cavarzere P, Camilot M, Teofoli F, Zampieri N, Tatò L. Prepubertal serum inhibin B in cryptorchid infants and in monorchid boys with compensatory testicular hypertrophy. Fertil Steril. 2008;90:2217-21.

17. Pollak SE, Furth EE, Kallen CB, Arakane F, Kiriakidou M, Kozarsky KF, Strauss JF 3rd. Localization of the steroidogenic acute regulatory protein in human tissues. J Clin Endocrinol Metab. 1997;82:4243-51.

18. Hadziselimovic F, Hoecht B, Herzog B, Buser MW. Infertility in cryptorchidism is linked to the stage of germ cell development at orchidopexy. Horm Res. 2007;68:46-52. https://doi.org/10.1159/000100874.

19. Hadziselimovic $F$, Hoecht B. Testicular histology related to fertility outcome and postpubertal hormone status in cryptorchidism. Klin Padiatr. 2008;220: 302-7. https://doi.org/10.1055/s-2007-993194.

\section{Publisher's Note}

Springer Nature remains neutral with regard to jurisdictional claims in published maps and institutional affiliations.

Ready to submit your research? Choose BMC and benefit from:
- fast, convenient online submission
- thorough peer review by experienced researchers in your field
- rapid publication on acceptance
- support for research data, including large and complex data types
- gold Open Access which fosters wider collaboration and increased citations
- maximum visibility for your research: over 100M website views per year
At BMC, research is always in progress.
Learn more biomedcentral.com/submissions

